\title{
Extracts with anti-inflammatory activities from Acanthopanax trifoliatus (L.) Merr. by inhibiting LPS-induced expression of iNOS and COX-2
}

\author{
Jiao LUO ${ }^{1}$, Shan XIAO ${ }^{1}$, Xiao-Jun $\mathrm{LI}^{2}$, Xiang-Qian $\mathrm{LIU}^{1 *}$ (D), Ok-Kyoung KWON ${ }^{3}$, Hyeong-Kyu $\mathrm{LEE}^{3}$, Sung-Kwon $\mathrm{KO}^{4}$, \\ Wan-Kyunn WHANG ${ }^{5}$, Chang-Soo YOOK ${ }^{6}$
}

\begin{abstract}
Acanthopanax trifoliatus (L.) Merr. have been used as folk medicine to treat various diseases traditionally and the young leaves and shoots of $A$. trifoliatus are popularly consumed as vegetables and herbal tea in southern China. In the study, we firstly tested the cytotoxicity and NO production of 18 fractions that extracted from the leaves, stems and roots of $A$. trifoliatus to select the bioactive fraction. The increasing evidence suggested that the dichloromethane extract prepared from stems of $A$. trifoliatus (ATSDC) have anti-inflammatory activity. Therefore, the study followed to investigate the effects of ATSDC on the inflammatory response and the molecular mechanisms underpinning this effect in lipopolysaccharide (LPS)-stimulated RAW264.7 cells. The manuscript showed that ATSDC effectively inhibited NO production in LPS-stimulated cells and significantly reduced the production of pro-inflammatory cytokines IL- 6 , at a dose of $40 \mu \mathrm{g} / \mathrm{mL}$, whereas TNF- $\alpha$ production tended to decrease under ATSDC treatment. We also confirmed a dose-dependent and significant inhibition of iNOS and COX-2 protein expression. In conclusion, ATSDC exerted strong inhibitory effect on the expression of iNOS and COX-2 protein in LPS-induced RAW 264.7 macrophages and could be potentially used in treatment of inflammatory-related diseases in the future.
\end{abstract}

Keywords: Acanthopanax trifoliatus (L.) Merr.; dichloromethane extract; anti-inflammatory activities; iNOS and COX-2; RAW 264.7 macrophages.

\section{Practical Application:}

1. Dichloromethane extract prepared from stems of Acanthopanax trifoliatus (L.) Merr. significantly reduced the production of NO, IL-6 and TNF- $\alpha$ in LPS-stimulated RAW264.7 cells.

2. It also exerted strong inhibitory effect on the expression of iNOS and COX-2 protein in LPS-induced RAW 264.7 macrophages.

3. The dichloromethane extract from stems of A. trifoliatus may be able to inhibit the inflammatory diseases.

4. This research also furnished a reliable theoretical and practical basis for the application of $A$. trifoliatus as a natural anti-inflammatory ingredient in health foods or complementary medicines in the future.

\section{Introduction}

Inflammation is a local response of the immune system to pathogens and damaged cells and is a vital defense mechanism (Nan et al., 2018). Macrophages play an important role in the inflammatory response and overexpress several mediators of inflammation in response to LPS-induced cell injury, such as tumor necrosis factor- $\alpha$ (TNF- $\alpha$ ), interleukin-6 (IL-6), nitric oxide (NO), inducible nitric oxide synthase (iNOS), and cyclooxygenase (COX)-2 (Zhang et al., 2018; Linghu et al., 2020). NO is mainly synthesized by iNOS which is largely involved in the pathophysiology of many inflammatory diseases (Cheng et al., 2016). COX-2 is another key enzyme in inflammatory responses (Dai et al., 2018). Inhibition of iNOS and COX-2 protein expression and/or enzyme activity have been considered as a potential mechanism of inflammation therapy (Tseng et al., 2018; Lee et al., 2020a). Various agents could serve as an important therapeutic target in the treatment of various inflammation-based pathologies, for example, steroidal hormones. Hence, nonsteroidal anti-inflammatory drugs (NSAIDs) are broadly used. However, NSAIDs have severe adverse effects as they damage the upper gastrointestinal tract by inhibiting prostaglandin synthesis (Li et al., 2019). Therefore, the development of new anti-inflammatory agents that are safer and more effective is ongoing (Lee, 2020b).

${ }^{1}$ School of Pharmacy, Hunan University of Chinese Medicine, Changsha, Hunan, China

${ }^{2}$ National Engineering Research Center for Modernization of Traditional Chinese Medicine, Hakka Medical Resources Branch, School of Pharmacy, Gannan Medical

University, Ganzhou, Jiangxi, China

${ }^{3}$ Korea Research Institute of Bioscience and Biotechnology, Daejeon, Korea

${ }^{4}$ Department of Oriental Medical Food \& Nutrition, Semyung University, Jecheon, Korea

${ }^{5}$ College of Pharmacy, Chung-Ang University, Seoul, Korea

${ }^{6}$ College of Pharmacy, Kyung Hee University, Seoul, Korea

*Corresponding author: 1xq0001cn@163.com 
Natural products are a key source and play an important role in discovering next generation medicines (Wang et al., 2020). Acanthopanax, one of the important medicinal genera of Araliaceae, is a plant genus that embraces over 70 plant species that are mainly distributed in China, Korea, Japan, Thailand, and the far-eastern regions of Russia (Yanzhong, 2012; Ganogpichayagrai \& Suksaard, 2020; Wang et al., 2020). Acanthopanax trifoliatus (L.) Merr. belongs to the Acanthopanax genus have been used as both traditional plant food and medicinal plant in the coastal region of South China (Chen et al., 2020). It is commonly used in traditional Chinese medicine with a ginseng-like activity for treating bruising, neuralgia, impotence, and gout in China (Chen et al., 2021). It also exhibits a rather good curative effect for treatment of common cold, jaundice, gastric pain, diarrhea, and ulcer (Sithisarn et al., 2011; Li et al., 2016). Moreover, the young leaves and shoots of $A$. trifoliatus are popularly consumed as vegetables in traditional southern Chinese cuisine that can be stir-fried or cooked in a soup (Peng et al., 2020). In addition, the local people of southern China have been using the leaves of this plant to make tea, which is called "Le Cai", for daily consumption at least 10 years for health management (Roslida et al., 2010; Sithisarn et al., 2011).

Taking into consideration the above facts, present study aimed to evaluate the anti-inflammatory activities of extracts from A. trifoliatus through effects on the production of TNF- $\alpha$, IL-6, and NO, as well as on the expression of iNOS and COX-2 by LPS-induced RAW 264.7 macrophages.

\section{Materials and methods}

\subsection{Plant materials}

The roots, stems, and leaves of $A$. trifoliatus were collected in November 2015 in Jiangxi (China). The plant species was confirmed by Professor XiangQian Liu (Hunan Key Laboratory of Traditional Chinese Medicine modernization, Hunan University of Chinese Medicine, Changsha, China), and the voucher specimen (no. 20151125) was deposited at the School of Pharmacy, Hunan University of Chinese Medicine (Changsha, China).

\subsection{Preparation of sample}

The air-dried stems of $A$. trifoliatus (ATS) were ground into a fine powder. The powder (30 g) was decocted with distilled water on reflux extraction for 2 hour and the other powder $(200 \mathrm{~g})$ was decocted with methanol $(\mathrm{MeOH}, 2 \times 2 \mathrm{~h})$ on reflux extraction before filtration. The water extract (ATSW) was freezedried, while the methanol extract (ATSM) was vacuum dried, the methanol extract was partitioned into $\mathrm{H}_{2} \mathrm{O}$ and extracted successively with petroleum ether (PE, 60-90), dichloromethane $\left(\mathrm{CH}_{2} \mathrm{Cl}_{2}\right)$, ethyl acetate (EtOAC), $n$-butanol $(n-\mathrm{BuOH})$ to obtain a petroleum ether extract (ATSPE), $\mathrm{CH}_{2} \mathrm{Cl}_{2}$ extract (ATSDC), EtOAc extract (ATSEA), and $n$-BuOH extract (ATSBU).

Using the method mentioned above, the roots of $A$. trifoliatus (ATR) were extracted to obtain ATRW, ATRM, ATRPE, ATRDC, ATREA, and ATRBU. The leaves of A. trifoliatus (ATL) were extracted to obtain ATLW, ATLM, ATLPE, ATLDC, ATLEA, and ATLBU. All fractions were stored at $4^{\circ} \mathrm{C}$ until analyzed.
Each fraction was dissolved in dimethyl sulfoxide (DMSO) for functional assays.

\subsection{Cell viability}

Cell viability assays were performed to determine the cytotoxicity of $A$. trifoliatus using 3-(4,5-dimethylthiazol-2-yl)2,5-diphenyltetrazolium bromide (MTT; Amresco, Solon, OH, USA) assay (Park et al., 2015). RAW 264.7 cells [American Type Culture Collection (ATCC); Manassas, VA, USA] were plated at a density of $1 \times 10^{5}$ cells $/ \mathrm{mL}$ in 96 -well plates and cultured at $37^{\circ} \mathrm{C}$ and $5 \% \mathrm{CO}_{2}$ in the Dulbecco's Modified Eagle's medium (DMEM; Gibco-BRL, Grand Island, NY, USA) with $100 \mu \mathrm{L}$ of $10 \%$ heat-inactivated fetal bovine serum (FBS; HyClone, Logan, UT, USA) for $5 \mathrm{~h}$, then RAW 264.7 cells were incubated $5 \mu \mathrm{L}$ with various concentrations of samples $(10,20$, and $40 \mu \mathrm{g} / \mathrm{mL})$ for $20 \mathrm{~h}$ and the treatment medium then completely replaced with MTT solution, $5 \mu \mathrm{L}$ of MTT solution $(5 \mathrm{mg} / \mathrm{mL})$ was then added to each well and the cells were cultured for a further $4 \mathrm{~h}$, The plates were removed from the incubator and the formazan crystals were dissolved by the addition of $100 \mu \mathrm{L}$ of dimethyl sulfoxide. The absorbance at $570 \mathrm{~nm}$ was read on a microplate reader (Spark10M, TECAN, Switzerland) as a measure of cell viability.

\subsection{NO and inflammatory cytokine assays}

The RAW 264.7 cells were seeded into a 96 well plate at a density of $2.5 \times 10^{4}$ cells/well and allowed to adhere for $4 \mathrm{~h}$. Then, cells were pretreated with various concentrations of samples $(10,20$, and $40 \mu \mathrm{g} / \mathrm{mL})$ for $1 \mathrm{~h}$ and stimulated with $5 \mu \mathrm{L}$ of lipopolysaccharide (LPS) at $0.5 \mu \mathrm{g} / \mathrm{mL}$ for $24 \mathrm{~h}$. To measure NO secretion, the cell supernatant was harvested and reacted with the Griess reagent [0.1\% N-(1-naphathyl)-ethylenediamine, $1 \%$ sulfanilamide in $5 \%$ phosphoric acid] for $10 \mathrm{~min}$ at room temperature in the dark. The absorbance at $540 \mathrm{~nm}$ was detected and the concentration was calculated using a nitrite standard solution.

The levels of IL-6 and TNF- $\alpha$ were measured using a commercial BD OptEIA ${ }^{\mathrm{TM}}$ ELISA kit (BD Biosciences, San Jose, CA, USA) according to the manufacturer's protocols.

\subsection{Western blot analysis}

Total protein $(30 \mu \mathrm{g})$ was separated on a $10 \%$ SDS polyacrylamide gel and transferred onto PVDF membranes (Millipore, Billerica, MA, USA). Each membrane was then incubated for $1 \mathrm{~h}$ in $5 \%$ skim milk in TBS-T buffer (0.1 M Tris- $\mathrm{HCl}, \mathrm{pH} 7.4,0.9 \% \mathrm{NaCl}$, $0.1 \%$ Tween-20) to block non-specific binding and was then incubated with primary antibodies that recognized iNOS (Cat. no. ADI-905-431, 1:1,000; obtained from Enzo Life Sciences, Farmingdale, NY, USA), COX-2 (Cat. no. sc-1747, 1:1,000; Santa Cruz Biotechnology, Santa Cruz, CA, USA), $\beta$-actin (Cat. no. MA515379, 1:2,000; Cell Signaling Technology, Danvers, MA, USA), Each protein was detected using a chemiluminescence detection system according to the instructions of the manufacturer (ECL; Amersham, Berkshire, UK) 


\subsection{Statistical analysis}

The results are expressed as the means \pm SEM of the sample size determinations. Statistical significance was determined using a two-tailed Student's t-test for independent means. The test results are reported as two-tailed $P$-values, where $P<0.05$ was considered to indicate a statistically significant difference.

\section{Results}

\subsection{Effect of 18 fractions extracted from ATR, ATS, and ATL on the viability of RAW264.7 macrophages}

The cytotoxic effect of 18 fractions extracted from ATR, ATS, ATL on LPS-stimulated RAW264.7 macrophages was determined at concentration of $20 \mu \mathrm{g} / \mathrm{mL}$ using the MTT assay. As shown in Figure 1A, the results of this analysis demonstrated that 18 fractions produced no significant change in cell viability compared to the untreated control group.

\subsection{Effect of 18 fractions extracted from ATR, ATS, and ATL on NO production of RAW264.7 macrophages}

NO is a signaling molecule which plays an important role in the inflammatory response. To examine whether 18 fractions extracted from ATR, ATS, ATL treatment could modulate NO production, we measured the NO secretion in LPS-induced RAW 264.7 cells after 18 fractions treatment separately at concentration of $20 \mu \mathrm{g} / \mathrm{mL}$, using a Griess reagent assay. As shown in Figure 1B, LPS treatment significantly induced NO production compared to that in the untreated control, while cells pretreated with ATSDC demonstrated a significant inhibition of NO production.

Then, the study determined the viability and NO production of ATSDC at different concentrations $(10,20$, and $40 \mu \mathrm{g} / \mathrm{mL})$ before the next inflammatory cytokine assays. As shown in Figure $2 \mathrm{AB}$, there was no significant change in cell survival at concentrations $(10,20$, and $40 \mu \mathrm{g} / \mathrm{mL})$ of ATSDC, which greatly reduced the production of NO in dose-dependent manner.

\subsection{Effect of ATSDC on the expression of IL-6 and TNF- $\alpha$ in RAW264.7 macrophages}

To determine whether the ability of ATSDC to inhibit inflammatory signaling corresponded to a reduction in the secretion of pro-inflammatory cytokines, we investigated cytokine secretion in LPS-activated macrophages using ELISA kits. As shown in Figure 2CD, at a dose of $40 \mu \mathrm{g} / \mathrm{mL}$, ATSDC treatment dramatically decreased the production of the pro-inflammatory IL- 6 and TNF- $\alpha$.

\subsection{Effect of ATSDC on iNOS and COX-2 protein expression}

Two other common mediators of inflammation are iNOS and COX-2. To evaluate whether ATSDC influence iNOS and COX-2 expression, we performed Western blot analysis. LPSstimulated cells exhibited a significant increase in iNOS and COX-2 expression, when compared to the untreated control. Treatment with ATSDC greatly down-regulated the production of iNOS and COX-2 stimulated by LPS in a concentrationdependent manner, as shown in Figure 3.
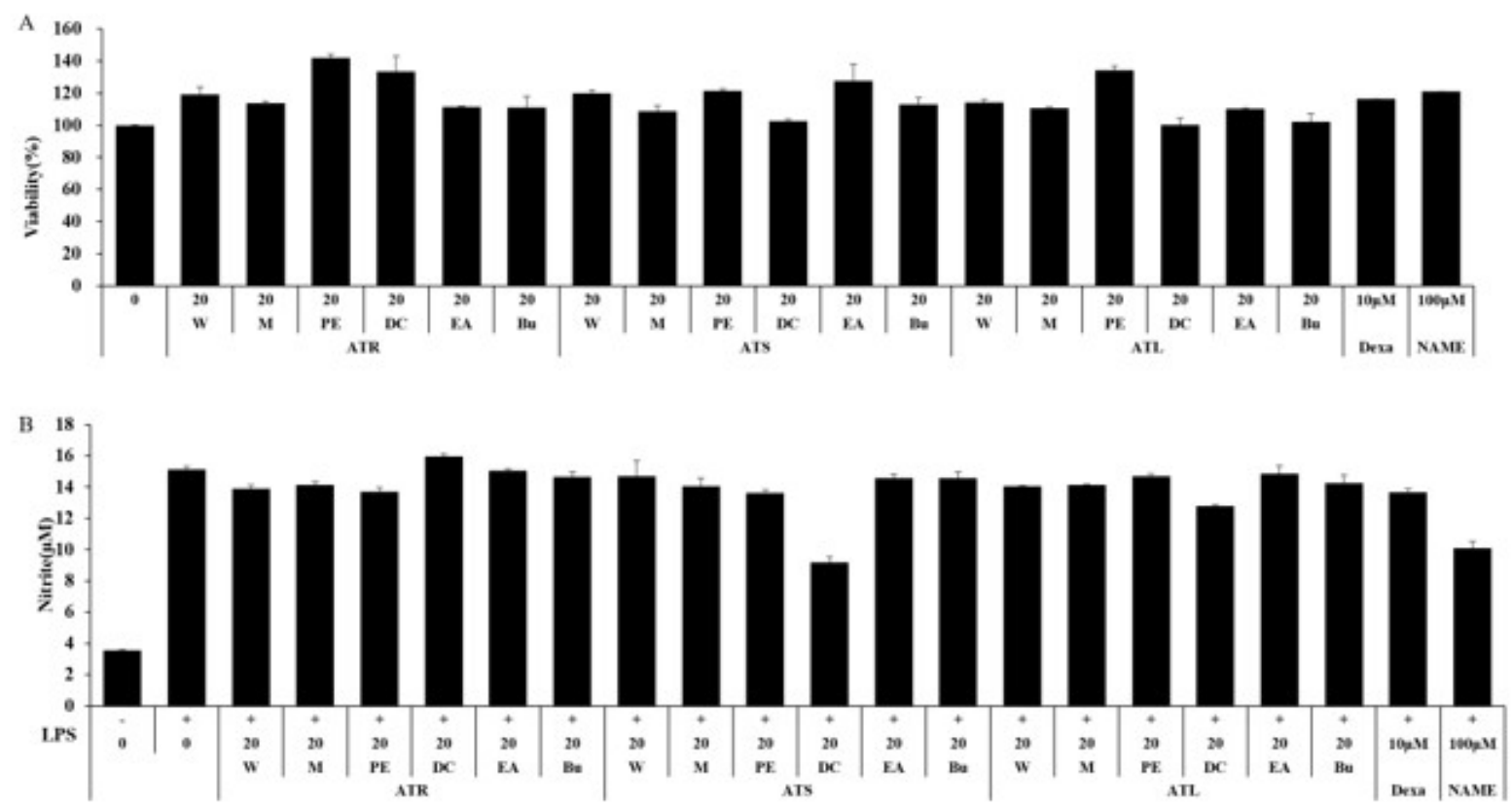

Figure 1. Effect of 18 different fractions on viability and NO production of LPS-induced RAW264.7 macrophages. Cells were pretreated for $1 \mathrm{~h}$ with 18 different fractions $(20 \mu \mathrm{g} / \mathrm{mL})$ and then treated with LPS $(0.5 \mu \mathrm{g} / \mathrm{mL})$ for $24 \mathrm{~h}$. (A) Cell viability was measured using an MTT assay; (B) NO production was measured using a Griess reagent assay; Dexamethasone (Dexa) and L-NG-monomethyl arginine (L-NMMA) were used as a positive control. Data were denoted as the mean \pm SEM $(n=3)$. 

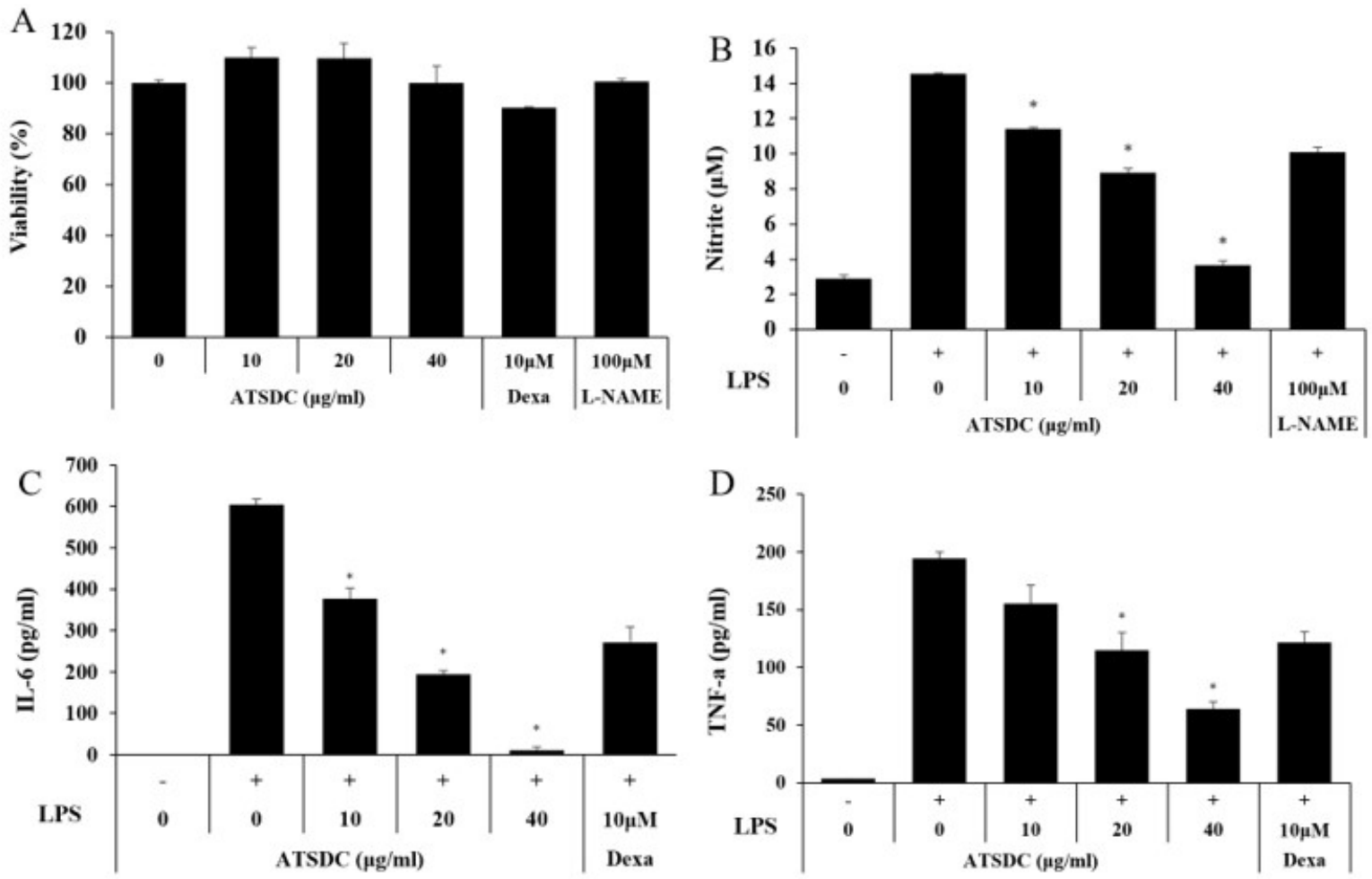

Figure 2. Effect of ATSDC on IL-6 and TNF- $\alpha$ production in LPS-induced RAW 264.7 macrophages. Cells were pretreated for 1h with ATSDC $(10,20$, and $40 \mu \mathrm{g} / \mathrm{mL})$ and then treated with LPS $(0.5 \mu \mathrm{g} / \mathrm{mL})$ for $24 \mathrm{~h}$. (A) Cell viability was measured using an MTT assay; (B) NO production was measured using a Griess reagent assay; Dexamethasone (Dexa) and L-NG-monomethyl arginine (L-NMMA) were used as a positive control. (C) IL- 6 and (D) TNF- $\alpha$ contents in the culture medium were determined by ELISA kits. Dexametasone (Dexa) was used as positive control. Data were denoted as the mean $\pm \operatorname{SEM}(n=3) .{ }^{*} P<0.05$, relative to control group.

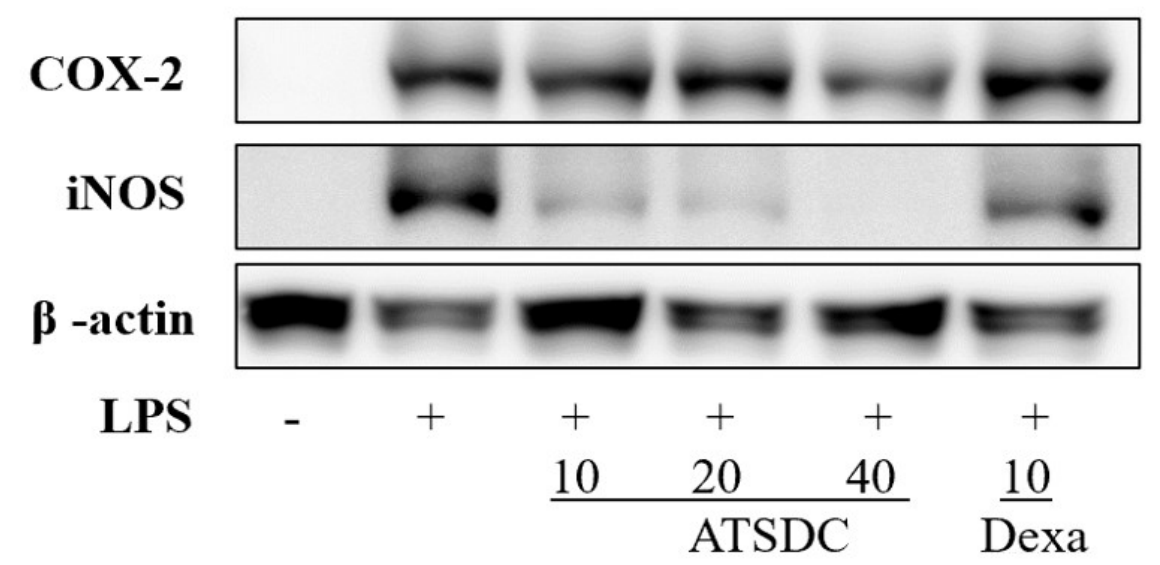

Figure 3. Effect of ATSDC on LPS-induced iNOS and COX-2 protein expression in RAW264.7 cells. Cells were pretreated for 1h with ATSDC $(10,20$, and $40 \mu \mathrm{g} / \mathrm{mL})$ and then treated with LPS $(0.5 \mu \mathrm{g} / \mathrm{mL})$ for $24 \mathrm{~h}$. iNOS and COX-2 and $\beta$-actin were detected by Western blot analysis.

\section{Discussion}

The current findings showed that both iNOS and COX-2 pathway were remarkable inhibited by the dichloromethane extract prepared from stems of $A$. trifoliatus. In addition, we also found that ATSDC inhibited NO, TNF- $\alpha$, and IL-6 production in LPSstimulated RAW264.7 cells.

Inflammation, a basic defense mechanism, protects organs from endogenous and exogenous stimuli, such as bacterial 
infection (Hou et al., 2018). However, excessive inflammation causes many diseases, such as inflammatory arthritis, asthma, and atherosclerosis (Lee et al., 2020a). LPS, a main component of outer cell membrane of Gram-negative bacteria, has been recognized as one of the most potent microbial initiators of inflammation (Li et al., 2019; Ko et al., 2019). Upon stimulation with LPS, RAW 264.7 macrophages cells could trigger the secretion of numerous inflammatory cytokines and mediators such as NO, TNF- $\alpha$, IL- 6 and so on (Luo et al., 2020). NO is a vital cellular signaling and defensing molecule involved in inflammation. It can be catalyzed via iNOS (Wang et al., 2019). The overproduction of $\mathrm{NO}$ has been linked to various inflammatory disorders (Lee et al., 2019). In addition, the production of NO is also regulated by the enzyme of COX-2 (Wu et al., 2020). Accumulated data indicate that COX-2 is involved in many inflammatory processes and induced in various disease, such as carcinomas and liver inflammation, suggesting that COX-2 plays a key role in inflammation (Cheng et al., 2016). In our study, we firstly tested the cytotoxicity and NO production of 18 fractions that extracted from the leaves, stems, roots of $A$. trifoliatus to select the bioactive fraction. Fraction of ATSDC shows great cell viability and significant inhibitory of NO production in dose-dependent manner compared to the other tested extracts. It demonstrated that the inhibitory effect of $\mathrm{NO}$ production of the stems of $A$. trifoliatus may better than the effect of leaves and roots of $A$. trifoliatus.

Pro-inflammatory cytokines such as TNF- $\alpha$, and IL- 6 can induce cell and tissue damage and also activate macrophages in various inflammation-associated diseases (Olajide et al., 2020). TNF- $\alpha$ induces synergy in NO production in LPS-stimulated macrophages, causing inflammatory responses such as fever, vasodilatation, and edema (Zelová \& Hošek, 2013). In addition, IL-6 is a multifunctional cytokine that plays a role in inflammation response through the stimulation of acute phase responses, hematopoiesis, and immune reactions (Zbakh et al., 2020). Therefore, targeting the inflammatory mediators and cytokines is a useful strategy in anti-inflammatory therapy (Lee et al., 2019). In the present study, we found that ATSDC significantly inhibited the LPS-induced production of NO by suppressing the expression of iNOS and COX-2 proteins in a dose-dependent manner, at a dose that was not cytotoxic. We also found that the pro-inflammatory cytokines, TNF- $\alpha$ and IL-6, were clearly inhibited by pre-treatment with ATSDC in LPS-stimulated RAW264.7 cells.

In the recent years, much attention has been focused on using traditional herbal medicines containing bioactive compounds as alternatives to the existing anti-inflammatory drugs that have many side effects (Hou et al., 2018; Zamani et al., 2019; Olajide et al., 2020; Lee et al., 2020a). To our knowledge, phytochemical investigations of A. trifoliatus lead to the identification of a series of chemical components including chlorogenic acid, isochlorogenic acids, sesquiterpenoids, stilbenoids, polysaccharides, flavonoids and triterpenoids (Yook et al., 1999; Kiem et al., 2004; Phuong et al., 2006; Sithisarn et al., 2011; Li et al., 2016; Peng et al., 2020). Biological studies also reported that $A$. trifoliatus extracts showed numerous biological activities including antioxidative, anti-inflammatory, anti-cancer, and neuroprotective effects (Sithisarn \& Jarikasem, 2009; Sithisarn et al., 2013; Wang et al.,
2014; Chen et al., 2019). However, the stems of A. trifoliatus has not been reported to have effects against inflammation in LPS-induced RAW264.7 macrophages. Hence, ATSDC could be further investigated to isolate and identify bioactive compounds that may be a potential therapeutic agent for the treatment of inflammation-related diseases.

\section{Conclusion}

In conclusion, the present study showed ATSDC treatment suppressed the NO production, likely through decreased the protein expression of iNOS and COX-2, and inhibited inflammatory cytokines such as TNF- $\alpha$, and IL- 6 in LPS-induced RAW264.7 cells. These results suggested that ATSDC possess effective anti-inflammatory activities and implies that the stem bark of $A$. trifoliatus may be able to inhibit the inflammatory diseases. In addition, the root bark of Acanthopanax plants, for example, Acanthopanax cortex, which is non-renewable resources have been traditionally used to treat many diseases (Chinese Pharmacopoeia Commission, 2015). In this research, ATS that are renewable and sustainable resources have significant anti-inflammatory activities and could be a new source of antiinflammatory drugs. Moreover, the leaves of $A$. trifoliatus that are popularly consumed as vegetables and herbal teas with high nutritional value and health care function in Guangdong province that has been prevalently planted for years (Roslida et al., 2010; Sithisarn et al., 2011; Peng et al., 2020). Hence, this research also furnished a reliable theoretical and practical basis for the application of $A$. trifoliatus as a natural anti-inflammatory ingredient in health foods or complementary medicines in the future.

\section{Abbreviations}

A. trifoliatus, Acanthopanax trifoliatus (Linn.) Merr.; ATR, the roots of A. trifoliatus; ATS, the stems of A. trifoliatus; ATL, the leaves of A. trifoliatus; ATRM, the methanol extract from ATR; ATRW, the water extract from ATR; ATRPE, the petroleum ether extract from ATR; ATRDC, the dichloromethane extract from ATR; ATREA, the ethyl acetate extract from ATR; ATRBU, the n-butanol extract from ATR; ATSM, the methanol extract from ATS; ATSW, the water extract from ATS; ATSPE, the petroleum ether extract from ATS; ATSDC, the dichloromethane extract from ATS; ATSEA, the ethyl acetate extract from ATS; ATSBU, the n-butanol extract from ATS; ATLM, the methanol extract from ATL; ATLW, the water extract from ATL; ATLPE, the petroleum ether extract from ATL; ATLDC, the dichloromethane extract from ATL; ATLEA, the ethyl acetate extract from ATL; ATLBU, the n-butanol extract from ATL; DMEM, Dulbecco's Modified Eagle's medium; L-NMMA, L-NG-monomethyl arginine; FBS, Fetal bovine serum; LPS, Lipopolysaccharide; NO, Nitric oxide; TNF- $\alpha$, Tumor necrosis factor- $\alpha$; IL-6, Interleukin-6; iNOS, Inducible nitric oxide synthase; COX-2, Cyclooxygenase 2; MTT, 3-(4,5-dimethylthiazol-2-yl)-2,5-diphenyltetrazolium bromide.

\section{Conflict of interest}

The authors declare no conflicts of interest. 


\section{Acknowledgements}

The authors are grateful to the colleagues who contributed to this study. This work is financially supported by the Natural Science Foundation of Hunan Province, China (grant numbers 2019JJ40223); First-class Discipline Project on Chinese Pharmacology of Hunan University of Chinese Medicine (school file number: "science" [2018] No. 3) and The Key Discipline of Biological Engineering of Hunan University of Chinese Medicine [2018] No. 3.

\section{References}

Chen, M., Qin, Y., Ma, H., Zheng, X., Zhou, R., Sun, S., Huang, Y., Duan, Q., Liu, W., Wu, P., Xu, X., Sheng, Z., Zhang, K., \& Li, D. (2019). Downregulating NF- $\kappa B$ signaling pathway with triterpenoids for attenuating inflammation: in vitro and in vivo studies. Food \& Function, 10(8), 5080-5090. http://dx.doi.org/10.1039/C9FO00561G. PMid:31361289.

Chen, S., Xu, Y., Liang, D., \& Wang, R. (2020). The complete chloroplast genome of Eleutherococcus trifoliatus (Araliaceae): a wild edible plant in the coastal region of South China. Mitochondrial DNA Part B, Resources, 5(1), 513-514. http://dx.doi.org/10.1080/23802359.2019 .1707131. PMid:33366626.

Chen, Z., Cheng, S., Lin, H., Wu, W., Liang, L., Chen, X., Zheng, X., He, Y., \& Zhang, K. (2021). Antibacterial, anti-inflammatory, analgesic, and hemostatic activities of Acanthopanax trifoliatus (L.) merr. Food Science \& Nutrition, 9(4), 2191-2202. http://dx.doi.org/10.1002/ fsn3.2190. PMid:33841835.

Cheng, A., Han, C., Fang, X., Sun, J., Chen, X., \& Wan, F. (2016). Extractable and non-extractable polyphenols from blueberries modulate LPS-induced expression of iNOS and COX-2 in RAW264.7 macrophages via the NF- $\mathrm{KB}$ signalling pathway. Journal of the Science of Food and Agriculture, 96(10), 3393-3400. http://dx.doi. org/10.1002/jsfa.7519. PMid:26538333.

Chinese Pharmacopoeia Commission. (2015). Pharmacopoeia of the people's Republic of China. Beijing: China Medical Science Press.

Dai, B., Wei, D., Zheng, N., Chi, Z., Xin, N., Ma, T., Zheng, L., Sumi, R., \& Sun, L. (2018). Coccomyxa gloeobotrydiformis polysaccharide inhibits Lipopolysaccharide-induced inflammation in RAW 264.7 macrophages. Cellular Physiology and Biochemistry, 51(6), 2523-2535. http://dx.doi.org/10.1159/000495922. PMid:30562752.

Ganogpichayagrai, A., \& Suksaard, C. (2020). Proximate composition, vitamin and mineral composition, antioxidant capacity, and anticancer activity of Acanthopanax trifoliatus. Journal of Advanced Pharmaceutical Technology \& Research, 11(4), 179-183. http://dx.doi. org/10.4103/japtr.JAPTR_61_20. PMid:33425701.

Hou, J., Gu, Y., Zhao, S., Huo, M., Wang, S., Zhang, Y., Qiao, Y., \& Li, $X$. (2018). Anti-inflammatory effects of aurantio-obtusin from seed of Cassia obtusifolia L. through modulation of the NF- $\mathrm{KB}$ pathway. Molecules, 24(4), 745. http://dx.doi.org/10.3390/molecules23123093. PMid:30486383.

Kiem, P. V., Cai, X. F., Minh, C. V., Lee, J. J., \& Kim, Y. H. (2004). Kaurane-type diterpene glycoside from the stem bark of Acanthopanax trifoliatus. Planta Medica, 70(3), 282-284. http:// dx.doi.org/10.1055/s-2004-818926. PMid:15114513.

Ko, E., Heo, S., Cho, S., Lee, W., Kim, S., Yang, H., Ahn, G., Cha, S., Kwon, S., Jeog, M. S., Lee, K. P., Jeon, Y., \& Kim, K. (2019). 3Bromo5(ethoxymethyl)1,2benzenediol inhibits LPS-induced pro-inflammatory responses by preventing ROS production and downregulating NF- $\mathrm{B}$ in vitro and in a zebrafish model. International
Immunopharmacology, 67, 98-105. http://dx.doi.org/10.1016/j. intimp.2018.11.021. PMid:30537636.

Lee, S. A., Park, B. R., Moon, S. M., Han, S. H., \& Kim, C. S. (2020a). Anti-inflammatory potential of Trifolium pratense L. leaf extract in LPS-stimulated RAW264.7 cells and in a rat model of carrageenaninduced inflammation. Archives of Physiology and Biochemistry, 126(1), 74-81. http://dx.doi.org/10.1080/13813455.2018.1493607 . PMid:30320514.

Lee, S., Cho, S., Li, Y., Bae, C., Park, K. M., \& Park, D. (2020b). Antiinflammatory effect of Curcuma longa and Allium hookeri co-treatment via NF- $\kappa \mathrm{B}$ and COX-2 pathways. Scientific reports, 10(1), 5718. http://dx.doi.org/10.1038/s41598-020-62749-7. PMid:32235914.

Lee, Y. M., Son, E., \& Kim, D. (2019). Treatment with Peanut Sprout Root Extract Alleviates Inflammation in a Lipopolysaccharide-Stimulated Mouse Macrophage Cell Line by Inhibiting the MAPK Signaling Pathway. International Journal of Molecular Sciences, 20(23), 5907. http://dx.doi.org/10.3390/ijms20235907. PMid:31775245.

Li, C., Tan, L., Wang, Y., Luo, C., Chen, H., Lu, Q., Li, Y., Yang, X., Chen, J., Liu, Y., Xie, J., \& Su, Z. (2019). Comparison of anti-inflammatory effects of berberine, and its natural oxidative and reduced derivatives from Rhizoma Coptidis in vitro and in vivo. Phytomedicine, 52, 272283. http://dx.doi.org/10.1016/j.phymed.2018.09.228. PMid:30599908.

Li, D., Zheng, X., Chen, Y., Jiang, S., Zhang, Y., Zhang, W., Wang, H., Du, Z., \& Zhang, K. (2016). Terpenoid composition and the anticancer activity of Acanthopanax trifoliatus. Archives of Pharmacal Research, 39, 51-58. http://dx.doi.org/10.1007/s12272-015-0655-y. PMid:26345267.

Linghu, K. G., Zhao, G. D., Xiong, W., Sang, W., Xiong, S. H., Tse, A. K. W., Hu, Y., Bian, Z., Wang, Y., \& Yu, H., (2020). Comprehensive comparison on the anti-inflammatory effects of three species of Sigesbeckia plants based on NF- $\mathrm{KB}$ and MAPKs signal pathways in vitro. Journal of Ethnopharmacology, 250, 112530. http://dx.doi. org/10.1016/j.jep.2019.112530. PMid:31883476.

Luo, Q., Sun, M., Guo, Y., Tan, S., Wu, X., Abassa, K., Lin, L., Liu, H., Jiang, J., \& Wei, X. (2020). Sodium butyrate protects against lipopolysaccharide-induced liver injury partially via the GPR43/ $\beta$-arrestin-2/NF- $\kappa B$ network. Gastroenterology Report, 9(2), 154165. http://dx.doi.org/10.1093/gastro/goaa085. PMid:34026223.

Nan, L., Nam, H. H., Choo, B. K., Park, J. C., Kim, D. G., Lee, J. H., \& Moon, K. H. (2018). An ethanolic extract of Allium hookeri root alleviates reflux esophagitis and modulates NF- $\mathrm{BB}$ signaling. Evidence-Based Complementary and Alternative Medicine, 2018, 1834681. http://dx.doi.org/10.1155/2018/1834681. PMid:30402117.

Olajide, O. A., Akande, I. S., Bezera, C. S. M. Fo., Lepiarz-Raba, I., \& Sousa, D. P. (2020). Methyl 3,4,5-trimethoxycinnamate suppresses inflammation in RAW264.7 macrophages and blocks macrophageadipocyte interaction. Inflammopharmacology, 28(5), 1315-1326. http://dx.doi.org/10.1007/s10787-020-00720-8. PMid:32418005.

Park, J., Kwon, O., Kim, J., Oh, S., Kim, J., Paik, J., Marwoto, B., Widjhati, R., Juniarti, F., Irawan, D., \& Ahn, K. (2015). Rhododendron album Blume inhibits iNOS and COX-2 expression in LPS-stimulated RAW264.7 cells through the downregulation of NF- $\kappa$ B signaling. International Journal of Molecular Medicine, 35(4), 987-994. http:// dx.doi.org/10.3892/ijmm.2015.2107. PMid:25784296.

Peng, Q., Chen, J., Duan, H., \& Wang, C. (2020). Determination of kaurenoic acid in Acanthopanax trifoliatus by Ultra-High Performance Liquid Chromatography coupled with Tandem Mass spectrometry (UHPLC-MS/MS). Scientific reports, 10(1), 3378. http://dx.doi. org/10.1038/s41598-020-60426-3. PMid:32099028.

Phuong, N. T., Lee, K. A., Jeong, S. J., Fu, C. X., Choi, J. K., Kim, Y. H., \& Kang, J. S. (2006). Capillary electrophoretic method for the 
determination of diterpenoid isomers in Acanthopanax species. Journal of Pharmaceutical and Biomedical Analysis, 40(1), 56-61. http://dx.doi.org/10.1016/j.jpba.2005.05.023. PMid:15990266.

Roslida, A. H., Siti, N. H., \& Fezah, O. (2010). Gastroprotective effect of Acanthopanax trifoliatus on experimentally induced acute ulcer in rats. Pharmacologyonline, 2, 828-841.

Sithisarn, P., \& Jarikasem, S. (2009). Antioxidant activity of Acanthopanax trifoliatus. Medical Principles and Practice, 18(5), 393-398. http:// dx.doi.org/10.1159/000226294. PMid:19648763.

Sithisarn, P., Muensaen, S., \& Jarikasem, S. (2011). Determination of caffeoyl quinic acids and flavonoids in Acanthopanax trifoliatus leaves by HPLC. Natural Product Communications, 6(9), 1289-1291. http://dx.doi.org/10.1177/1934578X1100600920. PMid:21941900.

Sithisarn, P., Rojsanga, P., Jarikasem, S., Tanaka, K., \& Matsumoto, K. (2013). Ameliorative effects of Acanthopanax trifoliatus on cognitive and emotional deficits in olfactory bulbectomized mice: an animal model of depression and cognitive deficits. Evidence-Based Complementary and Alternative Medicine, 2013, 701956. http:// dx.doi.org/10.1155/2013/701956. PMid:23573147.

Tseng, T., Lin, W., Chang, C., Lee, K., Tung, S., \& Kuo, H. (2018). Protective effects of morus root extract (MRE) against Lipopolysaccharideactivated RAW264.7 cells and CCl4-Induced mouse hepatic damage. Cellular Physiology and Biochemistry, 51(3), 1376-1388. http://dx.doi. org/10.1159/000495555. PMid:30481781.

Wang, H., Tseng, Y., Wu, H., Chu, F., Kuo, Y., \& Wang, S. (2014). Anti-proliferation effect on human breast cancer cells via inhibition of $\mathrm{pRb}$ phosphorylation by taiwanin E isolated from Eleutherococcus trifoliatus. Natural Product Communications, 9(9), 1303-1306. http://dx.doi.org/10.1177/1934578X1400900921. PMid:25918798.

Wang, Y., Zhang, H., Chen, Q., Jiao, F., Shi, C., Pei, M., Lv, J., Zhang, H., Wang, L., \& Gong, Z. (2020). TNF-á/HMGB1 inflammation signalling pathway regulates pyroptosis during liver failure and acute kidney injury. Cell Proliferation, 53(6), e12829. http://dx.doi. org/10.1111/cpr.12829. PMid:32419317.
Wang, Z., Liang, M., Li, H., Cai, L., \& Yang, L. (2019). Rice protein exerts anti-Inflammatory effect in growing and adult rats via suppressing NF- $\kappa$ B pathway. International Journal of Molecular Sciences, 20(24), 6164. http://dx.doi.org/10.3390/ijms20246164.

Wu, T., Shen, M., Guo, X., Huang, L., Yang, J., Yu, Q., Chen, Y., \& Xie, J. (2020). Cyclocarya paliurus polysaccharide alleviates liver inflammation in mice via beneficial regulation of gut microbiota and TLR4/MAPK signaling pathways. International Journal of Biological Macromolecules, 160, 164-174. http://dx.doi.org/10.1016/j. ijbiomac.2020.05.187. PMid:32464206.

Yanzhong, S. (2012). A dictionary of seed plant names (Vol. 2). Beijing: China Forestry Press.

Yook, C., Chang, S., Lai, J., Ko, S., Jeong, J., \& Nohara, T. (1999). Lupane-glycoside of Acanthopanax trifoliatus forma tristigmatis leaves. Archives of Pharmacal Research, 22, 629-632. http://dx.doi. org/10.1007/BF02975337. PMid:10615871.

Zamani, S., Emami, S. A., Iranshahi, M., Zamani Taghizadeh Rabe, S., \& Mahmoudi, M. (2019). Sesquiterpene fractions of Artemisia plants as potent inhibitors of inducible nitric oxide synthase and cyclooxygenase-2 expression. Iranian Journal of Basic Medical Sciences., 22(7), 774-780. PMid:32373299.

Zbakh, H., Zubía, E., Reyes, C., Calderón-Montaño, J. M., LópezLázaro, M., \& Motilva, V. (2020). Meroterpenoids from the brown alga Cystoseira usneoides as potential anti-inflammatory and lung anticancer agents. Marine Drugs, 18(4), 207. http://dx.doi.org/10.3390/ md18040207. PMid:32290492.

Zelová, H., \& Hošek, J. (2013). TNF-a signalling and inflammation: interactions between old acquaintances. Inflammation Research, 62(7), 641-651.http://dx.doi.org/10.1007/s00011-013-0633-0. PMid:23685857.

Zhang, H., Ren, Q., Ren, Y., Zhao, L., Yang, F., Zhang, Y., Zhao, W., Tan, Y., \& Shen, X. (2018). Ajudecumin A from Ajuga ovalifolia var. calantha exhibits anti-inflammatory activity in lipopolysaccharideactivated RAW264.7 murine macrophages and animal models of acute inflammation. Pharmaceutical Biology, 56(1), 649-657. http:// dx.doi.org/10.1080/13880209.2018.1543331. PMid:31070535. 